\title{
Body weight, body measurements and slaughter characteristics of Madura cattle raised in Pamekasan District, East Java Province, Indonesia
}

\author{
PENI WAHYU PRIHANDINI ${ }^{1, \boldsymbol{}}$, DYAH MAHARANI ${ }^{2}$, SUMADI $^{2}$ \\ ${ }^{1}$ Beef Cattle Research Station. Jl. Pahlawan, Grati, Pasuruan 67184, East Java, Indonesia. Tel.: +62-343-481131, Fax.: +62-343-481132, \\ "email: peniprihandini@pertanian.go.id \\ ${ }^{2}$ Department of Animal Breeding and Reproduction, Faculty of Animal Science, Universitas Gadjah Mada. Jl. Fauna No. 3, Bulaksumur, Sleman 55281, \\ Yogyakarta, Indonesia
}

Manuscript received: 11 March 2020. Revision accepted: 1 July 2020.

\begin{abstract}
Prihandini PW, Maharani D, Sumadi. 2020. Body weight, body measurements, and slaughter characteristics of Madura cattle raised in Pamekasan District, East Java Province, Indonesia. Biodiversitas 21: 3415-3421. This study was designed to analyze the body weight, body measurements and slaughter characteristics of Madura cattle raised in Pamekasan district, East Java province, Indonesia. A total of 2,373 records on live body weight and body measurements (body length, height at withers and chest girth), and 69 records on slaughter traits (slaughter, carcass, and meat weight, as well as carcass and meat percentage) from both sexes were used. Sampled animals were divided into three groups based on age (calf: 0- to10-month-old; young: 11- to 24-month-old; adult: >24-monthold). The data were analyzed using independent sample t-test to assess significant differences between sex groups and subjected to multiple linear regression analyses to obtain prediction equations of body weight from body measurements, carcass weight from slaughter weight, and meat weight from slaughter- and carcass-weight. Results showed that body weight, height at withers, and chest girth between male and female cattle in all age groups were significantly different $(\mathrm{P}<0.05)$. Male cattle showed higher slaughter weight, carcass weight and carcass percentage mean values than female cattle. Body measurements showed high correlation with body weight ( $\mathrm{r}$ $\geq 0.80)$. Height at withers, body length, and chest girth represented good body measurements to predict body weight $\left(R^{2}=\right.$ from 0.65 to $0.83)$. Moreover, as observed, high correlations between slaughter weight and carcass- $\left(r=0.94 ; R^{2}=0.89\right)$ and meat-weight $(r=0.99$; $\left.\mathrm{R}^{2}=0.98\right)$ would imply that meat weight could be predicted accurately from slaughter- and carcass-weight.
\end{abstract}

Keywords: Body weight, body measurements, carcass weight, meat weight, Madura cattle

\section{INTRODUCTION}

Livestock is a sub-sector in Indonesia's agriculture industry which equates to its significant contribution to the value of the country's agriculture as a whole. It has multiple roles in providing livelihood and food for the people in the country. The main goals of the livestock industry are to increase livestock population, meat production, and the supply of industrial raw materials and to improve farmers' living standards. It has been known that beef and chicken are the most common protein sources in the country. The demand for livestock products especially beef is increasing due to rapid population growth, economic development, and increased education levels.

Beef cattle have an important role in providing animalderived nutrients. National beef consumption per capita in 2016-2017 increased by $12.50 \%$ from $0.417 \mathrm{~kg} /$ capita to $0.469 \mathrm{~kg} / \mathrm{capita}$ (Ditjenpkh 2018). Aside from eggs and milk, red meat is the main livestock product due to its high socio-economic value. Red meat is a valuable source of protein and essential nutrients that are beneficial for the human body (FAO 2015). Considering the significant roles of cattle herd in the country, development and utilization programs of indigenous cattle must be taken into consideration and addressed to achieve the main goals of the livestock industry and to reduce imports of cattle. Meat self-sufficiency through the improvement of indigenous cattle is ideal but challenging. The productivity of indigenous cattle, therefore, must be improved through well-designed selection programs (Hartatik et al. 2019).

Indonesia possesses number of indigenous cattle distributed over wide ecological zones; many of which still managed traditionally. For instance, Madura cattle are one of the country's main cattle breeds, particularly on the island of Madura. Madura cattle are defined as crossbreed derived from Bali (Bos javanicus) and zebu (Bos indicus) cattle (Sutarno and Setyawan 2015). Pamekasan regency is a regency on the island of Madura, and the population of Madura cattle in this regency is around 155.104 head in 2016 (Ditjenpkh 2018). In addition, Madura cattle play very important economic and socio-cultural roles for rural households by providing labor, additional income, and savings. On the island of Madura, they are commonly raised for draught animals, bull racing (Karapan), and cow conformation contests (Sonok) (Widi et al. 2013).

Genetic improvement of the local livestock breeds through appropriate techniques or selection in breeding programs is the need of the day (Yakubu 2010). Indigenous livestock breeds need to be characterized, because 
characterization, as well as inventory and monitoring of animal genetic resources (AnGR) are essential for designing sustainable management and facilitating effective planning of how and where they can best be used and developed (FAO 2015).

Selective breeding in cattle has been very successful in increasing the quantity of beef production. Body weight, body measurements, and slaughter traits are of great economic importance to cattle producers (Said et al. 2017; Priyanto et al. 2019). Growth and carcass composition are influenced by genetic, physiological age, sex, nutrition and environment (Casas et al. 2012; Irshad et al. 2013). Other factors such as age at slaughter, weight of animal, and preand post-slaughter handling affect carcass composition as well (Never 2015). Pre-slaughter handling activities occur on the farm, during transportation, and at the slaughterhouse. Poor handling processes prior to slaughter can cause physiological stress which will adversely reduce animal body weight, influence the carcass quality and quantity, and subsequently reduce profit. Therefore, body weight, body measurements, and slaughter traits need to be recorded and included as selection criteria in breeding programs of Madura cattle. In addition, body weight, body measurements, and slaughter data of local beef cattle are important in estimating domestic beef supply and designing a strategy for the improvement of local beef cattle (Priyanto et al. 2019). Little is known about the body weight, body measurements, and slaughter traits of Madura cattle especially those raised in Pamekasan regency. This study was designed to analyze the body weight, body measurements, and slaughter characteristics of Madura cattle raised in Pamekasan district, East Java province, Indonesia. The results could prove valuable for improvement and development of Madura cattle in the future.

\section{MATERIALS AND METHODS}

\section{Study sites and animal feeding}

This study was conducted in Pamekasan regency, East Java from December 2016 to April 2017. The study sites are presented in Figure 1. Nine villages from three subdistricts (Larangan, Pamekasan, and Pasean) were used for the collection of data on body weight and body measurements; Larangan Dalam, Peltong, Montok, Patemon, Gladakanyar, Toronan, Sotabar, Bindang, and Dempo Barat villages. In addition, a slaughterhouse located in Patemon village of Pamekasan sub-district was used for the collection of data on slaughter traits. All animals sampled for the collection of body weight and body measurement data were raised by local livestock keepers as beef cattle, locally known as "Sapi Sayur". Those animals were fed thrice daily; field grass and elephant grass were given at 6:00 am; field grass, corn stover and rice straw were given at 11:30 am and 7:30 pm. A mixture of boiled water, rice bran, banana flowers, salt, and molasses was given at 7:00 am.

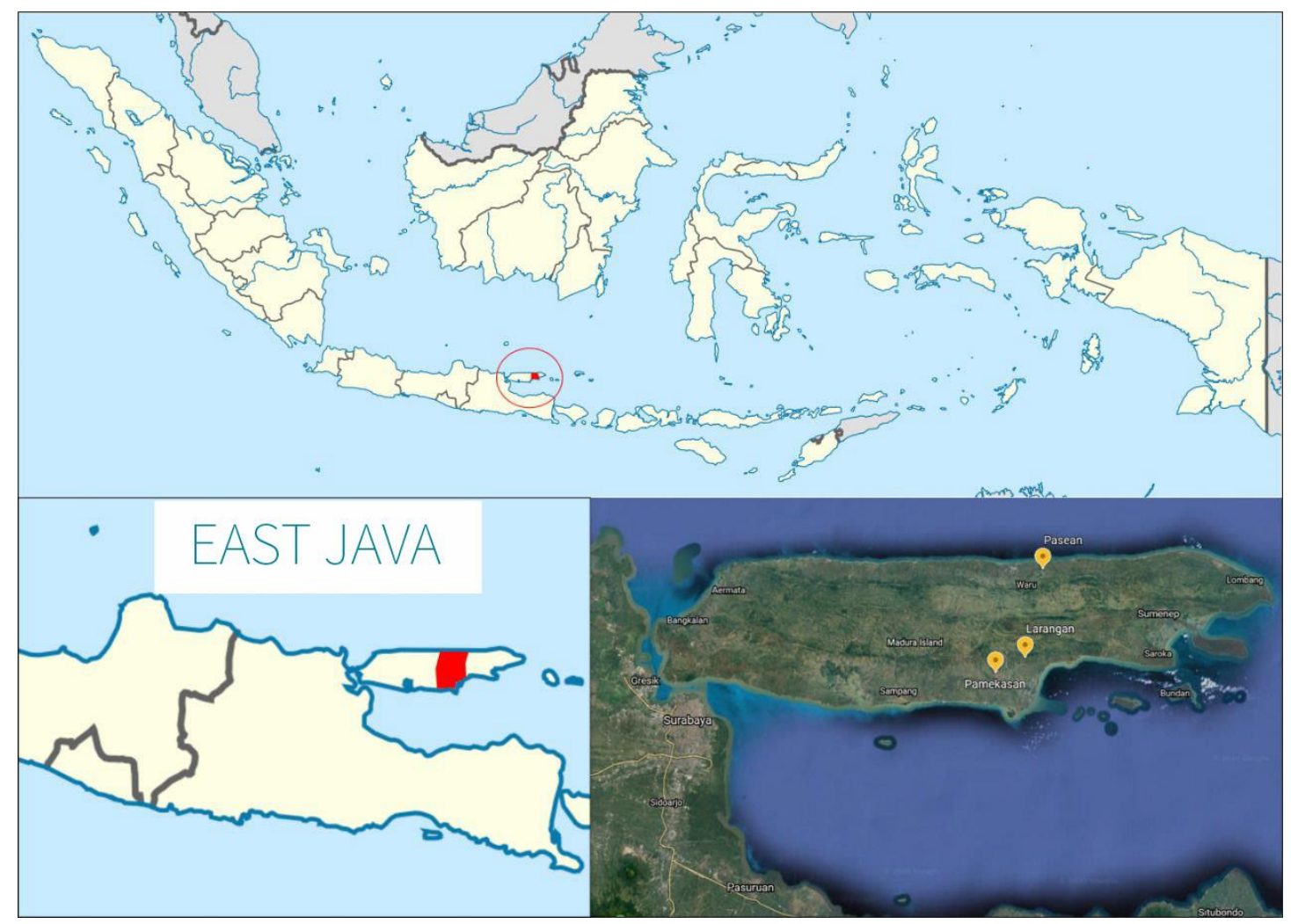

Figure 1. A map showing three sub-districts (Larangan, Pamekasan, and Pasean) of Pamekasan district, East Java province, Indonesia as the study sites 


\section{Data collection}

A total of 2,373 records on live body weight and body measurements (body length, height at withers and chest girth), and 69 records on slaughter traits (slaughter weight, weight, and percentage of carcass and meat) from both sexes were used in this study. Data on body weight and body measurements in both male and female cattle were divided into three groups: calf ( $0-10$ months of age), young (11-24 months of age) and adult (>24 months of age). For slaughter trait data, animals were divided according to age into two groups (10-24 months of age and $>24$ months of age) in both sexes. Data were collected by directly weighing and measuring the cattle. Body measurements of Madura cattle were measured based on the procedures of the national standardization agency of Indonesia (BSN 2013). Direct observations were performed to determine the age of animals, body weight, body measurements, and slaughter traits. Age of the tested animals was determined according to the method described previously (Torell et al. 2003). Briefly, at 2 years of age the permanent pinchers appear and the central permanent incisors are fully developed; at 2-2.5 years of age the first intermediate pair of incisors appear; at 3-3.5 years of age, the second intermediates or laterals are cut and are on a level with the first intermediates and begin to wear at 4 years. Data on carcass traits were collected by similar slaughterers to avoid large variation because of separating carcass parts. All slaughtered animals came from Pamekasan regency to ensure that they received relatively similar feed management. To minimize the effect of reproduction status like pregnancy, all-female cattle were non-pregnant cows.

Live body weight (in $\mathrm{kg}$ ) was the body weight of an animal before being slaughtered. Body measurements (in $\mathrm{cm}$ ) including body length (BL), height at withers (HW), and chest girth (CG) were measured before being slaughtered. Carcass weight (in $\mathrm{kg}$ ) was obtained by weighting all carcass parts. Carcass percentage (in \%) was obtained by dividing carcass weight by live cattle body weight and multiplied by $100 \%$. Meat weight (in $\mathrm{kg}$ ) was obtained by weighting all carcass parts after removal of bones. For meat percentage (in \%), it was obtained by dividing meat weight by live cattle body weight and multiplied by $100 \%$.

\section{Statistical analysis}

Data obtained were tabulated as means and standard deviations. Data were also analyzed using independent sample t-test to assess significant differences between males and females for all traits observed, and subjected to multiple linear regression analysis to obtain prediction equations of body weight from body measurements, carcass weight from slaughter weight, and meat weight from slaughter- and carcass-weight. All analyses were performed using the SPSS software ver. 16 (SPSS Inc, Chicago, IL, USA). The following equations were used for the analysis of multiple linear regression analysis.

$$
\mathrm{Yj}=\mathrm{a}+\beta_{1} \mathrm{X}_{1}+\beta_{2} \mathrm{X}_{2}+\beta_{3} \mathrm{X}_{3}+\mathrm{ej} \quad \text { (Equation 1) }
$$

Where: $\mathrm{Yj}$ is the dependent variable (body weight); $\mathrm{a}$ is the intercept; $X_{1}, X_{2}$, and $X_{3}$ are the independent variables height at withers, body length, and chest girth, respectively; $\beta_{1}, \beta_{2}$, and $\beta_{3}$ are the regression coefficient of the variables $\mathrm{X}_{1}, \mathrm{X}_{2}$ and $\mathrm{X}_{3}$; and ej is the residual random error

$$
\mathrm{Yj}=\mathrm{a}+\beta_{\mathrm{i}} \mathrm{X}_{\mathrm{i}}+\mathrm{ej}
$$

(Equation 2)

Where: $\mathrm{Yj}$ is the dependent variable (hot carcass weight); $\mathrm{a}$ is the intercept; $\mathrm{X}_{\mathrm{i}}$ is the independent variable slaughter weight; $\beta_{i}$ is the regression coefficient of the variable $\mathrm{Xi}$; and ej is the residual random error

$$
\mathrm{Yj}=\mathrm{a}+\beta_{1} \mathrm{X}_{1}+\beta_{2} \mathrm{X}_{2}+\mathrm{ej}
$$

(Equation 2)

Where: $\mathrm{Yj}$ is the dependent variable (meat weight); $\mathrm{a}$ is the intercept; $X_{1}$ and $X_{2}$ are the independent variables slaughter weight and hot carcass weight, respectively; $\beta_{1}$ and $\beta_{2}$ are the regression coefficient of the variables $X_{1}$ and $\mathrm{X}_{2}$; and ej is the residual random error.

\section{RESULTS AND DISCUSSION}

\section{Body weight and body measurements}

Mean values and standard deviations of body weight and body measurements of the Madura cattle are presented in Table 1. In calf and young cattle groups, female cattle gained higher mean values of body weight, height at withers, body length, and chest girth than male cattle $(\mathrm{P}<0.05)$. On the other hand, in adult cattle groups, male cattle gained higher values for those traits than female cattle $(\mathrm{P}<0.05)$. Chest girth $(156.26 \pm 15.86 \mathrm{~cm})$ of Madura cattle at 24 months of age obtained from this study was higher than $135.26 \pm 6.09 \mathrm{~cm}$ and $140.81 \pm 3.01 \mathrm{~cm}$ in the same breed and age reported by Nurgihartiningsih et al. (2016) and Hartatik et al. (2012), respectively. Results of this study were comparable to those reported by Volkandari et al. (2012); they reported $118.86 \pm 2.02 \mathrm{~cm}$ for height at withers, $121.19 \pm 10.62 \mathrm{~cm}$ for body length and $151.97 \pm$ 16.14 for chest girth at yearling age of Madura cattle. Mean body weight $(284.75 \pm 74.05 \mathrm{~kg})$ of adult Madura cattle observed in this study was slightly lower than that reported by Widi et al. (2012). They reported mean body weight 294 $\mathrm{kg}$ of Madura cattle raised under standard management and fed with high-quality feed. Body measurements of Madura cattle observed in this study were comparable to the findings of Prihandini et al. (2018) in the same breed; they found $103.08 \pm 6.26 \mathrm{~cm}$ for height at withers, $99.74 \pm 7.66$ $\mathrm{cm}$ for body length and $117.21 \pm 9.28 \mathrm{~cm}$ for chest girth. Widyas et al. (2020) observed height at withers (129.71 \pm $9.26 \mathrm{~cm}$ ) of the Madura cattle at $>3$ years old, which relatively higher than the result of this study.

Sex is a source of variation in the growth and development of intramuscular adipocytes (Park et al. 2018). Significant differences in body weight and body measurements between male and female cattle have been reported in F1 progeny of Charolais sires and Simmental dams; male cattle were heavier in body weight, conformation, and daily gain than female cattle (Bureš and 
Bartoň 2012). Growth rate and hormonal differences between the sexes may induce variation in body weight and body measurements (Casas et al. 2012; Irshad et al. 2013). According to the rearing purposes, a recent study classified Madura cattle into three subpopulations (commercial, Karapan, and Sonok) with distinctive physical characteristics; Sonok cattle group is found to have higher body weight and body measurements than other cattle groups (Widyas 2019). It was noted that Madura cattle observed in this study came from Pamekasan regency where the cattle population is high. Animals included in this study were those raised for beef cattle production, and neither Sonok nor Karapan cattle were sampled. Hence, variation in body weight and body measurements of Madura cattle observed in this study may not be associated with rearing purposes.

Results showed that adult male cattle gained higher values for body weight and body measurements than adult female cattle. This may correspond to the fact that bulls are typically used as superior bulls (Pemacek) and thus, fed with high-quality feed. Bulls are commonly fed with field grass, elephant grass, cassava peels, eggs (free-range chickens), and a mixture of boiled water, rice bran, banana flower, salt and molasses. Bull racing (Karapan) and cow conformation contests (Sonok) are traditional cultural events on the island of Madura (Widi et al. 2013), which are created to encourage people to raise Madura cattle. Livestock keepers who reared Madura cattle for Sonok and Karapan purposes may give more attention towards giving their animals high-quality feed and good standard management practices than commercial cattle.

Growth traits are commonly used as selection criteria in beef cattle breeding programs due to the economic importance of these traits. The main goal of the genetic improvement program is to increase body weight and body measurements of local cattle breeds. Results of previous studies showed that body weight is positively correlated with body measurement (Mekparyup et al. 2013; Lukuyu et al. 2016; Vanvanhossou et al. 2018). Siddiqui et al. (2015) observed high correlation of body weight with heart girth, body length, and height at withers in Sahiwal cattle. An increase in weight gain will result in increased muscle fibers with greater glycolytic activity, which subsequently affects meat aging and hence tenderness, which are the major factors in consumer meat preferences.

According to the national standardization agency of Indonesia (BSN 2013), the height at withers (HW) of Madura cattle are classified into three grades; adult male cattle at 24-36 months of age are classified into Grade 1 (HW >136 cm), Grade 2 (HW >132 cm) and Grade 3 (HW $>124 \mathrm{~cm}$ ), while female cattle at 18-24 months of age are classified into Grade 1 (HW >120), Grade 2 (HW >117 $\mathrm{cm})$ and Grade $3(\mathrm{HW}>114 \mathrm{~cm})$. Based on this reference, adult Madura cattle observed in this study were classified into Grade 3 (males) and Grade 2 (females). This may indicate poor genetic quality of the cattle and lack of superior bulls in the breeding flocks and hence, genetic improvement for height at withers through selection programs has to be considered in the future.

To predict live body weight from linear body measurements in male and female cattle in three age groups, a stepwise multiple linear regression analysis was performed, and the results indicated a positive correlation between linear body measurements with body weight. As shown in Table 2, the results include regression equation, coefficient of correlation (r) and coefficient of determination $\left(\mathrm{R}^{2}\right) . \quad \mathrm{r}$ represents the magnitude of correlation between a single or a combination of body measurements with live body weight, while $\mathrm{R}^{2}$ represents the proportion of the total variability explained by the model. The results showed that correlation between body weight and body measurements ranged from 0.80 to 0.91 . In male cattle group, the highest $\mathrm{R}^{2}(0.81)$ was found which indicated that a combination of height at withers, body length, and chest girth accounted for $83 \%$ of the total variance in body weight. When chest girth alone was taken into the model, however, it only accounted for $65 \%$ of the total variance in body weight. In female cattle groups, a combination of height at withers, body length, and chest girth accounted for $69 \%$ (calf), 65\% (young), and 65\% (adult) of the total variance in body weight.

Compared to previous studies, chest girth was found to correlate with body weight in cattle (Milla et al. 2012; Siddiqui et al. 2015) and in horse (Takaendengan et al. 2012). Chest girth has been identified to be a useful estimation parameter for body weight in Bali cattle and female Madura cattle (Nurgiartiningsih et al. 2011; Nurgiartiningsih et al. 2016). Similar to the findings of this study, high correlation (0.92) between chest girth and body weight was observed in Bali cattle (Ni'am et al. 2012). At the field level when there is a difficulty to take whole measurements, chest girth has been reported to be more accurate and reliable in predicting live body weight than other linear body measurements (Tesfay et al. 2017). Estimation of live body weight in cattle is very useful to estimate breeding age, marketing weight, feeding requirement, weight gain, and cash value (Tariq et al. 2013). According to the results of this study, male cattle groups had relatively higher $\mathrm{R}^{2}$ compared to female cattle groups indicating that the use of body measurements in predicting live body weight might more accurate in males than in females. In addition, height at withers, body length, and chest girth represented good body measurements to predict body weight.

\section{Slaughter characteristics}

Mean values and standard deviations of slaughter characteristics of the Madura cattle are shown in Table 3. Most of the slaughtered animals in male and female groups were more than 24 months of age. Male cattle had higher mean values of all measured traits than female cattle. Slaughter weight $(218.89 \pm 35.13 \mathrm{~kg}$ in females and 238.04 $\pm 59.34 \mathrm{~kg}$ in males) of Madura cattle observed in this study was comparable to that of the same breed (345.82 \pm $88.55 \mathrm{~kg}$ ) reported by Priyanto et al. (2019). Carcass percentage $(52.22 \pm 3.37 \%$ in females and $52.84 \pm 6.57 \%$ in males) of Madura cattle was close to that of Pasundan cattle $(53.02 \%)$ reported by Said et al. (2017). Carcass weight increased in line with the increasing slaughter weight. 
Table 1. Mean values and standard deviations of body weight and body measurements in Madura cattle

\begin{tabular}{|c|c|c|c|}
\hline \multirow{2}{*}{ Item } & \multicolumn{2}{|c|}{ Sex } & \multirow{2}{*}{ Total } \\
\hline & Male & Female & \\
\hline \multicolumn{4}{|l|}{ Calf (0-10 month of age) } \\
\hline Number of animals (head) & 120 & 474 & 594 \\
\hline Age (month) & $4.42 \pm 2.55$ & $6.58 \pm 2.23$ & $6.14 \pm 2.45$ \\
\hline Body weight $(\mathrm{kg})^{*}$ & $101.74 \pm 43.51$ & $133.89 \pm 60.24$ & $127.39 \pm 58.51$ \\
\hline Height at withers $(\mathrm{cm})^{*}$ & $89.41 \pm 12.58$ & $103.33 \pm 13.02$ & $100.52 \pm 14.08$ \\
\hline Body length $(\mathrm{cm}) *$ & $84.20 \pm 15.55$ & $100.91 \pm 16.85$ & $97.54 \pm 17.89$ \\
\hline Chest girth $(\mathrm{cm})^{*}$ & $99.47 \pm 17.22$ & $121.00 \pm 68.78$ & $116.65 \pm 62.51$ \\
\hline \multicolumn{4}{|c|}{ Young cattle (11-24 months of age) } \\
\hline Number of animals (head) & 118 & 722 & 840 \\
\hline Age (month) & $15.49 \pm 4.47$ & $17.28 \pm 4.78$ & $17.03 \pm 4.77$ \\
\hline Body weight $(\mathrm{kg})^{*}$ & $197.55 \pm 65.14$ & $213.13 \pm 56.62$ & $210.94 \pm 58.11$ \\
\hline Height at withers $(\mathrm{cm})^{*}$ & $113.50 \pm 9.64$ & $117.62 \pm 10.86$ & $117.04 \pm 10.79$ \\
\hline Body length $(\mathrm{cm}) *$ & $112.17 \pm 13.53$ & $118.51 \pm 13.56$ & $117.62 \pm 13.73$ \\
\hline Chest girth $(\mathrm{cm})^{*}$ & $137.06 \pm 15.48$ & $142.70 \pm 16.83$ & $141.90 \pm 16.76$ \\
\hline \multicolumn{4}{|l|}{ Adult cattle (>24 months of age) } \\
\hline Number of animals (head) & 78 & 861 & 939 \\
\hline Age (month) & $38.33 \pm 8.97$ & $47.54 \pm 16.29$ & $46.78 \pm 16.01$ \\
\hline Body weight $(\mathrm{kg})^{*}$ & $306.66 \pm 95.04$ & $282.76 \pm 71.59$ & $284.75 \pm 74.05$ \\
\hline Height at withers $(\mathrm{cm})^{*}$ & $128.74 \pm 9.46$ & $123.42 \pm 9.63$ & $123.86 \pm 9.73$ \\
\hline Body length $(\mathrm{cm})^{*}$ & $135.52 \pm 14.36$ & $127.02 \pm 11.36$ & $127.72 \pm 11.87$ \\
\hline Chest girth $(\mathrm{cm})^{*}$ & $161.44 \pm 16.19$ & $155.79 \pm 15.75$ & $156.26 \pm 15.86$ \\
\hline
\end{tabular}

Note: *There is significant differences between male and female cattle groups for traits observed $(\mathrm{P}<0.05)$

Table 2. Results of multiple regression analysis between body weight and body measurements in Madura cattle

\begin{tabular}{lllrr}
\hline Sex & Age & Regression equation & $\mathbf{r}^{\mathbf{R}^{\mathbf{2}}}$ & 0.81 \\
\hline Male & Calf & $\mathrm{Y}=-95.86+1.99 \mathrm{X} 3$ & 0.91 & 0.83 \\
& Young & $\mathrm{Y}=-426.92+2.70 \mathrm{X} 1+1.41 \mathrm{X} 2+1.17 \mathrm{X} 3$ & 0.84 & 0.71 \\
& Adult & $\mathrm{Y}=-492.42+4.95 \mathrm{X} 1$ & 0.83 & 0.69 \\
Female & Calf & $\mathrm{Y}=-246.80+3.07 \mathrm{X} 1+0.55 \mathrm{X} 2+0.06 \mathrm{X} 3$ & 0.80 & 0.65 \\
& Young & $\mathrm{Y}=-240.47+0.63 \mathrm{X} 1+1.10 \mathrm{X} 2+1.75 \mathrm{X} 3$ & 0.81 & 0.65 \\
& Adult & $\mathrm{Y}=-440.09+1.56 \mathrm{X} 1+1.75 \mathrm{X} 2+1.98 \mathrm{X} 3$ & 0.86 & 0.72 \\
\hline
\end{tabular}

Note: Y: body weight; X1: height at withers; X2: body length; X3: chest girth; r: coefficient of correlation; R2: coefficient of determination

Table 3. Slaughter characteristics of Madura cattle

\begin{tabular}{lcccccc}
\hline \multirow{2}{*}{ Item } & \multicolumn{2}{c}{ Female } & \multicolumn{2}{c}{ Male } & \multicolumn{2}{c}{ Total } \\
\hline Number of animals (head) & $\mathbf{1 0 - 2 4}$ months & $\mathbf{> 2 4}$ months & Total & $\mathbf{1 0 - 2 4}$ months & >24 months & 19 \\
Slaughter weight (kg) & $211.88 \pm 46.66$ & $220.33 \pm 32.87$ & $218.89 \pm 35.13$ & $227.67 \pm 11.59$ & $239.77 \pm 64.07$ & $238.04 \pm 59.34$ \\
Carcass weight (kg) & $113.28 \pm 30.01$ & $114.56 \pm 17.35$ & $114.35 \pm 19.65$ & $125.75 \pm 16.65$ & $125.33 \pm 39.39$ & $125.39 \pm 36.82$ \\
Carcass percentage (\%) & $53.10 \pm 4.45$ & $52.05 \pm 3.14$ & $52.22 \pm 3.37$ & $55.10 \pm 4.80$ & $52.48 \pm 6.84$ & $52.84 \pm 6.57$ \\
Meat weight (kg) & $84.10 \pm 27.28$ & $84.81 \pm 15.40$ & $84.68 \pm 17.59$ & $94.15 \pm 14.09$ & $94.70 \pm 34.01$ & $94.62 \pm 31.79$ \\
Meat percentage (\%) & $39.02 \pm 5.65$ & $38.42 \pm 3.54$ & $38.52 \pm 3.90$ & $41.23 \pm 4.23$ & $39.36 \pm 7.59$ & $39.62 \pm 7.18$ \\
\hline
\end{tabular}

Table 4. The results of multiple regression analysis between slaughter weight and carcass weight of Madura cattle

\begin{tabular}{lccc}
\hline \multicolumn{1}{c}{ Component } & Regression equation & r & $\mathbf{R}^{\mathbf{2}(\%)}$ \\
\hline Relationship between slaughter weight and carcass weight & $\mathrm{Y}_{1}=-7.35+0.56 \mathrm{X}$ & 0.94 & $89 \%$ \\
Relationship between slaughter- and carcass-weight and meat weight & $\mathrm{Y}_{2}=-9.76-0.12 \mathrm{X}_{1}+1.05 \mathrm{X}_{2}$ & 0.99 & $98 \%$ \\
\hline
\end{tabular}

Note: Y1: carcass weight; Y2: meat weight; X: slaughter weight; X1: slaughter weight; X2: carcass weight; r: coefficient of correlation;

$\mathrm{R} 2$ : coefficient of determination 
Carcass percentage of male and female groups was quite similar. Slaughter and carcass traits are influenced by genetics, physiological age, sex, nutrition, and environment (Casas et al. 2012; Irshad et al. 2013). Furthermore, less feed volume and drinking water in the digestive system can increase carcass percentage (Hafid et al. 2019). According to age classification, female Madura cattle observed in this study were mostly slaughtered at $>24$ months of age, which is the productive age of Madura cattle. A previous case study reported that reasons for slaughtering cows at productive ages were poor cattle performance, lower cow price than bulls, long calving interval, leg fracture, and reproductive organ dysfunctions (Soejosopoetro 2011). In addition, the need for cash income is the major reason for slaughtering productive cows (Nur et al. 2019).

The relationship between body weight and carcass weight was determined using multiple linear regression analysis. Slaughter weight and carcass weight were considered as independent and dependent variables, respectively. As shown in Table 4, the relationship between slaughter weight and carcass weight followed a regression of $\mathrm{Y} 1=-7.35+0.56 \mathrm{X}(\mathrm{r}=0.94 ; \mathrm{R} 2=89 \%)$. Meanwhile, slaughter weight and carcass weight in relation to meat weight were determined in a regression $\mathrm{Y} 2=-9,76-$ $0,12 \mathrm{X} 1+1,05 \mathrm{X} 2(\mathrm{r}=0.99 ; \mathrm{R} 2=98 \%)$. The results showed that both simple regression equations had positive values. The first equation indicated that an increase in slaughter weight will be followed by an increase in carcass weight, while the second equation implied that an increase in slaughter weight and carcass weight will be followed by an increase in meat weight. Compared to the first equation, the second equation which combined slaughter- and carcass weight variables was found to be the best equation for predicting meat weight.

In summary, body weight and body measurements of Madura cattle varied between male and female cattle in all age groups. Male cattle showed higher slaughter weight, carcass weight and carcass percentage mean values than female cattle. A combination of height at withers, body length, and chest girth could be used in predicting live body weight. Slaughter weight could be used to predict carcass weight. Moreover, a high correlation observed between meat weight and slaughter- and carcass-weight would imply that meat weight could be predicted fairly accurately from slaughter- and carcass-weight of the Madura cattle.

\section{ACKNOWLEDGEMENTS}

Ministry of Agriculture of Indonesia through the Agency of Agricultural Research And Development funded this research (No.95/Kpts/KP.320/H.1/1/2017). The authors thank the Farmers and Agricultural and Livestock Bureau of Pamekasan for assistance in data collection.

\section{REFERENCES}

Bureš D, Bartoň L. 2012. Growth performance, carcass traits and meat quality of bulls and heifers slaughtered at different ages. Czech $\mathrm{J}$ Anim Sci 57 (1): 34-43.
Casas E, Thallman RM, Cundiff LV. 2012. Birth and weaning traits in crossbred cattle from Hereford, Angus, Norwegian Red, Swedish Red and White, Wagyu, and Friesian sires. J Anim Sci 90 (9):2916-20.

Directorate General of Livestock and Animal Health Service (Ditjen PKH). 2018. Livestock and Animal Health Statistics. Indonesian Ministry of Agriculture, Jakarta. https://ditjenpkh.pertanian.go.id/userfiles/File/Buku_Statistik_2018__Final_ebook.pdf?time=1543210844103 [Indonesian]

FAO. 2015. The Second Report on the State of the World's Animal Genetic Resources for Food and Agriculture, edited by B.D. Scherf \& D. Pilling. FAO Commission on Genetic Resources for Food and Agriculture Assessments. Rome http://www.fao.org/3/ai4787e/index.html

Hafid H, Hasnudi, Bain HA, Nasiu F, Inderawati, Patriani P, Ananda SH. 2019. Effect of fasting time before slaughtering on body weight loss and carcass percentage of Bali cattle. IOP Conf. Series: Earth and Environmental Science 260 (2019) 012051. doi:10.1088/17551315/260/1/012051

Hartatik T, Hariyono DNH, Adinata Y. 2019. Genetic diversity and phylogenetic analysis of two Indonesian local cattle breeds based on cytochrome $b$ gene sequences. Biodiversitas 20 (1):17-22.

Hartatik T, Mahardika DA, Widi TSM, Baliarti E. 2012. Characteristic and Performance of Limousin-Madura Grade and Madura Cows in Sumenep and Pamekasan Regencies. Buletin Peternakan 33 (3):143147.

Irshad A, Kandeepan G, Kumar S, Ashish Kumar A, Vishnuraj MR, Shukla V. 2013. Factors influencing carcass composition of livestock: a review. J Anim Prod Adv 3 (6):177-186.

Lukuyu MN, Gibson JP, Savage DB, Duncan AJ, Mujibi FDN, Okeyo AM. 2016. Use of body linear measurements to estimate live weight of crossbred dairy cattle in smallholder farms in Kenya. Springerplus 5:63.

Mekparyup J, Saithanu K, Arunkeeree N. 2013. Estimation of body weight of Holstein-Friesian cattle with multiple regression analysis. $\begin{array}{lllll}\text { Int } & \text { Appl }\end{array}$ https://www.researchgate.net/publication/273950588

Milla AP, Mahagoub MMM, Bushara I. 2012. Estimation of live body weight from heart girth, body length and condition score in Nilotic cattle - Southern Sudan. J Anim Sci Adv 2: 453-457.

National Standardization Agency of Indonesia (BSN). 2013. Bibit Sapi Madura Bagian 2. Madura. SNI 7651.2:2013. ICS 65.020.30. BSN, Jakarta.

Never A. 2015. Some major factors affecting carcass composition in goats. Sci J Animal Sci 4: 81-88. [Indonesian]

Ni'am HUM, Purnomoadi A, Dartosukarno S. 2012. Correlation between statistic vital and body weight in female Bali cattle at different age groups. Animal Agriculture Journal 1:541-556.

Nur RB, Pattiselanno AE, Girsang W. 2019. The behavior of farmers in the slaughter of female cows (case study in Ambon city abattoir). AGRILAN: Jurnal Agribisnis Kepulauan 7 (1): 1-16. [Indonesian]

Nurgiartiningsih VMA, Budiarto A, Kusmartono, Suyadi. 2016. Evaluation of performance in female Madura cattle in Madura Island, Indonesia. Animal Production 18 (3):125-130.

Nurgiartiningsih VMA. 2011. Map of genetic potency of pure Madura Cattle at four districts in Madura. Journal of Tropical Animal Production 12 (2):23-32.

Park SJ, Beak SH, Jung DJS, Kim SY, Jeong IH, Piao MY, Kang HJ, Fassah DM, Na SW, Yoo SP, Baik M. 2018. Genetic, management, and nutritional factors affecting intramuscular fat deposition in beef cattle - A review. Asian-Australas J Anim Sci 31 (7):1043-1061.

Prihandini WP, Maharani D, Suparta G, Sumadi. 2018. Estimates of heritability and breeding values for growth traits in Madura cattle reared in Pamekasan regency. Asian J Microbiol Biotechnol Environ Sci 20 (3):1041-1044.

Priyanto R, Nuraini H, Muladno, Ismail M, Wijayanto H. 2019. Slaughter, carcass and non-carcass characteristics of local cattle and buffalo in Indonesia. Pak J Nutr 18 (2):117-124.

Said S, Putra WBP, Anwar S, Agung PP, Yuhani H. 2017. Phenotypic, morphometric characterization and population structure of Pasundan cattle at West Java, Indonesia. Biodiversitas 18 (4):1638-1645.

Siddiqui MU, Lateef M, Bashir MK, Bilal MQ, Muhammad G, Mustafa MI, Rehman SU. 2015. Estimation of live weight using different body measurements in Sahiwal cattle. Pak J Life Soc Sci 13 (1):12-15.

Soejosopoetro B. 2011. Studi tentang Pemotongan Sapi Betina Produktif di RPH Malang. Jurnal Ternak Tropika 12 (1): 22-26. [Indonesian] 
Sutarno, Setyawan AD. 2015. Review: Genetic diversity of local and exotic cattle and their crossbreeding impact on the quality of Indonesian cattle. Biodiversitas 16 (2):327-354.

Takaendengana BJ, Paputungana U, Noorb RR, Adiani S. 2012. Live weight estimation by chest girth, body length and body volume formula in Minahasa local horse. Media Peternakan August 35 (2):8084.

Tariq M, Younas M, Khan AB, Schlecht E. 2013. Body measurement and body condition scoring as basis for estimation of live weight in Nili-Ravi buffaloes. Pak Vet J 33 (3):325-329.

Tesfay HH, Banerjee AK, Mummed YY. 2017. Live body weight and linear body measurements of indigenous sheep population in their production system for developing suitable selection criteria in Central Zone of Tigray, Northern Ethiopia. Afr J Agric Res 12 (13):10871095.

Torell R, Bruce B, Kvasnicka B. 2003. Methods of Determining Age of Cattle. Available from http://avc-beef.org/AgingCattleGriffin/AgingCattle-CL712.pdf.
Vanvanhossou SFU, Diogo RVC, Dossa LH. 2018. Estimation of live body weight from linear body measurements and body condition score in theWest African Savannah Shorthorn cattle inNorth-West Benin. Cogent Food \& Agriculture 4: 1549767.

Volkandari SD, Hartatik T, Sumadi. 2012. Growth estimation of Madura and Limousin Cross Madura cattle in Pamekasan District. Proceeding of the 15Th AAAP Animal Science Congress. Thammasat University, Pathum Thani, 26-30 November 2012.

Widi TSM, Udo HMJ, Oldenbroe JK, Budiastra IGS, Baliarti E, van Zijpp AJ. 2013. Unique cultural values of Madura cattle: is crossbreeding a threat? Anim Genet Resour 54:141-152.

Widyas N, Prastowo S, Haryanto R, Nugroho T, Widi TSM. 2019. Madura cattle stratification as a signature of traditional selection and diverse production systems. IOP Conf Series: Earth Environ Sci 387: 012120

Yakubu A. 2010. Path coefficient and path analysis of body weight and biometric traits in Yankasa lambs. Slovak J Anim Sci 43 (1):17-25. 